\title{
不安定性䅡椎による䅡椎症性骨䯣症の治療経験
}

\author{
熊本整形外科病院整形外科 \\ 城石達光・栄輝 巳 \\ 内田仁・平川敬
}

\section{Treatment of Cervical Spondylotic Myelopathy caused by Unstable Cervical Spine}

\author{
Tatsuhiro Shiroishi, Terumi Sakae, Hitoshi Uchida, \\ and Kei Hirakawa \\ Department of Orthopaedic Surgery, \\ Kumamoto Orthopaedic Hospital, \\ Kumamoto, Japan
}

\begin{abstract}
(Objective) Anterior spinal fusion was performed on patients who developed myelopathy as a result of mild cervical instability, and the results of treatment and degree of instability were investigated. (Subjects and Methods) Subjects were seven patients (four male, three female; ages 42 to 78 years; mean age 61.7) who developed myelopathy due to cervical instability after November 2001. JOA scores were compared before and after surgery, and cervical instability was assessed using plain X-ray (dynamic imaging). (Results) The degree of slippage of the cervical spine as assessed on plain Xrays ranged from 2 to $5 \mathrm{~mm}$ (mean: $3.3 \mathrm{~mm}$ ). The direction of slippage was forward in three patients and backward in four patients. Slippage was confirmed in one intervertebral space in six patients $(\mathrm{C} 4 / 5$ in three patients, $\mathrm{C} 3 / 4$ in two patients, and $\mathrm{C} 5 / 6$ in one patient) and in two intervertebral spaces in one patient (C3/4 and $\mathrm{C} 4 / 5)$. In all patients, MRI confirmed a change in the spinal luminance in these areas. Preoperatively, the JOA score (maximum score of 17 points) ranged from 7 to 15 points (mean: 11.3 points), and postoperatively, it ranged from 11 to 17 points (mean: 14.2 points), thus confirming improvement. Although the patients were followed up for only a short period of time, the clinical courses for these patients were favorable.
\end{abstract}

Key words： anterior spinal fusion (前方固定), unstable cervical spine (不安定性頚椎), myelopathy（脊髄症）

\section{は じめに}

頚椎不安定性は頚椎症性脊䯣症の動的発症因子の一 つと考えられる，不安定性に関しては，まだはつきり とした定義はない，今回微小な䅡椎不安定性（前後の すべりに限定）にもかかわらず脊䯣症を生じた症例に 対し, 手術を行い, その不安定性および治療成績につ いて検討した.
対象

対象は 2001 年 11 月以降に, 䫝椎不安定性（前方あ るいは後方のすべり）により脊髄症を生じ，手術を施 行した 7 例で, 男性 4 例, 女性 3 例, 年齢は 42 歳〜 78 歳（平均 61.7 歳）。罹患部位は 1 椎間 6 例 (C4/5 が 3 例，C $3 / 4$ が 2 例，C5/6が 1 例）であった． 2 椎 間は 1 例（C3/4，C4/5）であった。全例同部位に 
MRI にて髄内輝度変化を認めた。術後経過観察期間 は $2 \sim 4$ ケ月（平均 3.3 ケ月）であった．検討項目は 動態単純 X 線でのすべりの程度と種類, 手術適応, 術前後の JOA スコアを検討した. すべりの評価方法 は前方, 後方すべりに分け, すべりは下位隣接椎体後 縁の接線と上位隣接椎体後下角との距離で測定し, 動 的脊柱管狭窄は下位椎体後上角と上位椎弓下縁との距 離あるいは上位椎体後下角と下位椎弓上縁との距離 （以下椎体椎弓間距離）で評価した（図 1)。手術適応 は頝椎不安定性により脊髄症の増悪を認め, 固定にて

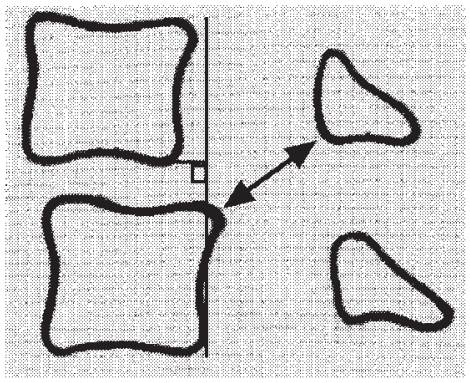

前方すべり
症状軽快する場合，前方固定の適応（2 椎間まで）と 考えた.

結

果

すべりは前方が 3 例，後方が 4 例で， C $4 / 5$ に 4 例 と最も多く, 2 5mm (平均 $3.3 \mathrm{~mm}$ ), 動態椎体椎

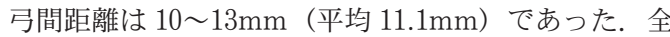
例単純 X 線にて，脊柱管は整復位で $13 \sim 14 \mathrm{~mm}$ (平 均 $13.6 \mathrm{~mm}$ ）で，明らかな狭窄は認めなかった。前方, 後方すべりとも全例術後 JOA スコアの改善を認めた.

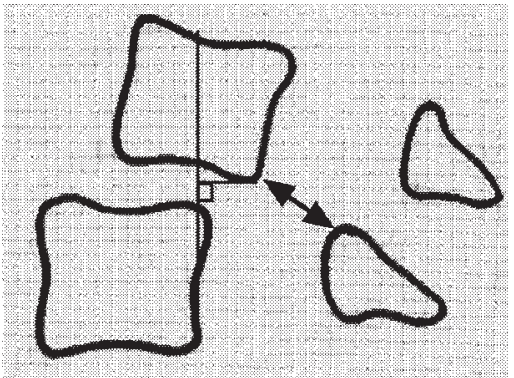

後方すべり

図 1 澒椎前後すべりの評価

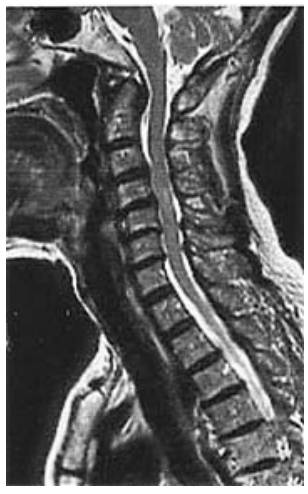

a

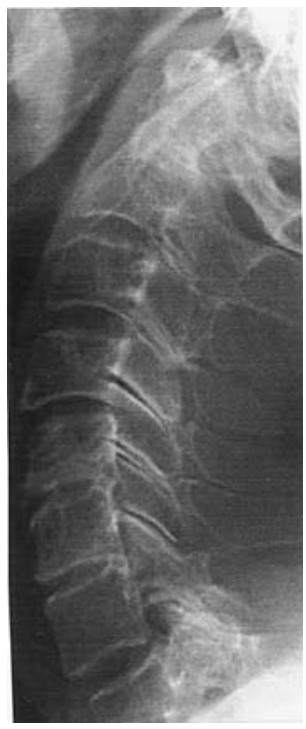

$\mathrm{c}$

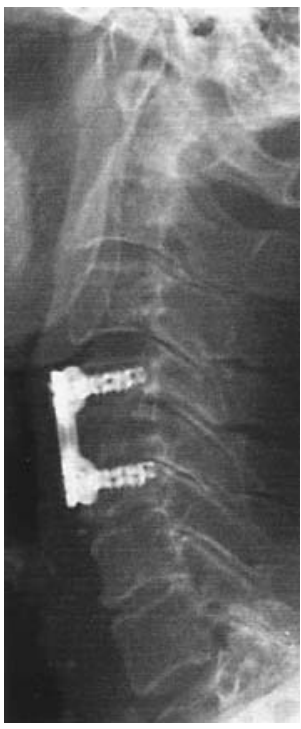

d

図 2 症例 1

a : MRIT2 にて C4/5 に脊䯣䯣内輝度変化を認める.

b : $3 \mathrm{~mm}$ の $\mathrm{C} 4$ 前方すべりを認める.

$\mathrm{c}:$ 後屈

$\mathrm{d}: \mathrm{C} 4 / 5$ 頚椎前方固定術を施行した. 


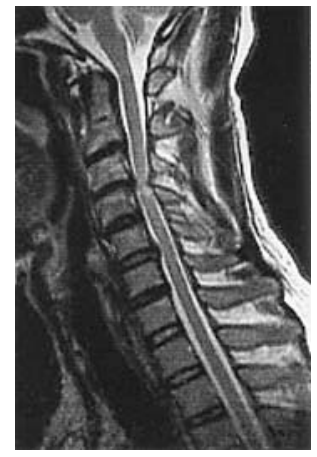

a

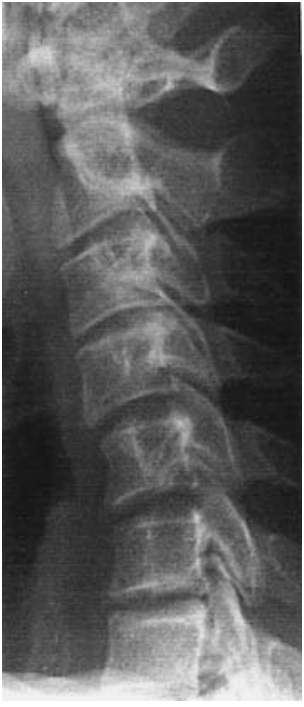

b

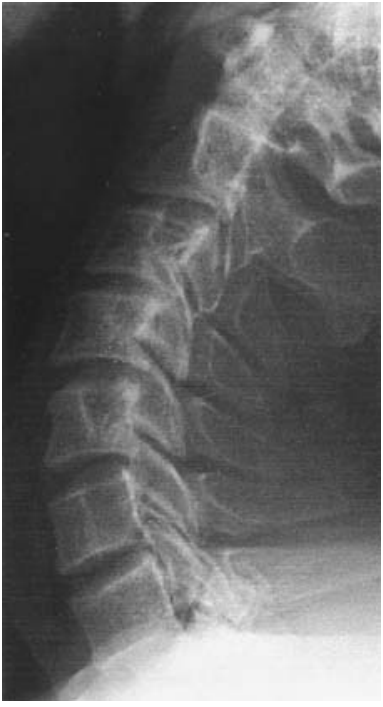

c

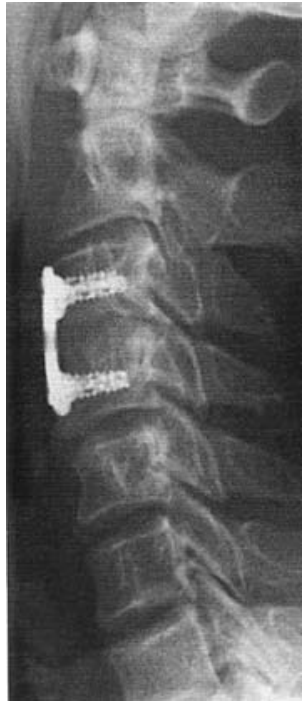

d

図 3 症例 2

a : MRIT2 にて C $3 / 4$ に春髄髄内輝度変化を認める.

$\mathrm{b}:$ 前屈

c : $3 \mathrm{~mm}$ の C3 後方すべりを認める

$\mathrm{d}: \mathrm{C} 3 / 4$ 难椎前方固定術を施行した.

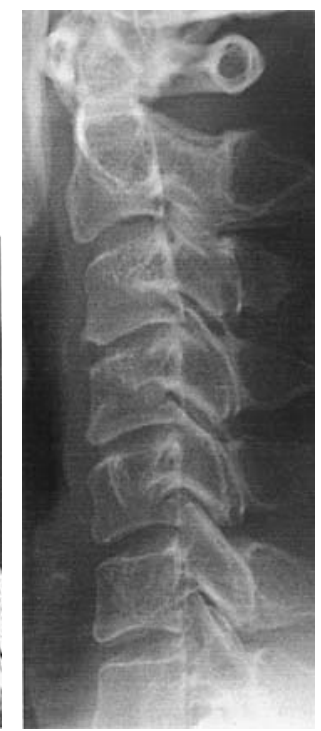

b

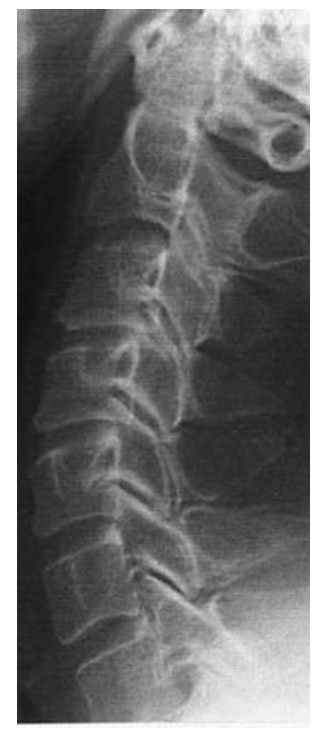

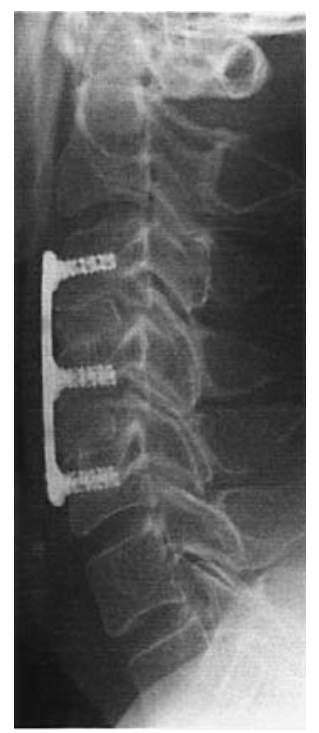

d

図 4 症例 3

a : MRIT2 にて C $3 / 4$, C4/5 に脊骾髄内輝度変化を認める.

$\mathrm{b}:$ 前屈

c : C3 は $5 \mathrm{~mm}, \mathrm{C} 4$ は $2 \mathrm{~mm}$ の後方すべりを認める.

$\mathrm{d} ： \mathrm{C} 3 / 4, \mathrm{C} 4 / 5$ 頚椎前方固定術を施行した. 


\section{症例}

（症例 1） 72 歳，女性. $3 \mathrm{~mm}$ の C4 前方すべりがあ

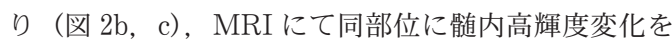
認めた（図 $2 \mathrm{a}$ )。巧緻障害, 歩行障害増悪のため, C4/5 の前方固定術施行し（図 2d）, 症状改善した.

（症例 2） 47 歳, 男性. $3 \mathrm{~mm}$ の C3 後方すべりを認 め（図 3b，c），MRI で同部位に髄内高輝度変化を認 めた（図 3a）。両手のしびれと左手の巧緻障害, 歩行 障害も出現し, C3/4の前方固定術施行し（図 $3 \mathrm{~d}$ ), 症状改善した.

（症例 3） 43 歳, 男性. C3 は $5 \mathrm{~mm}, \mathrm{C} 4$ は $2 \mathrm{~mm} の$ 後方すべりを認め（図 $4 b, c)$ ，同部位に MRI にて髄 内高輝度変化を認めた（図 $4 \mathrm{a} ）$ ．両四肢のしびれ，四 肢麻痺出現し，歩行困難となり， C $3 / 4, \mathrm{C} 4 / 5$ の前方 固定術を施行した（図 4d)。現在独歩となり，筋力も 正常となつた.

\section{考察}

頚椎不安定性に関して，諸家(1)23445)67788) の報告が散 見されるが, Penning ${ }^{8)}$, Epstein ら 2)31 よる脊髄圧迫を報告し，また片岡，福井ら ${ }^{4) 56)}$ は動的 狭窄が $12 \mathrm{~mm}$ 以下と報告している。国分 ${ }^{7)}$ は脊髄症 における後方すべりの発生率が高いと報告している. 特に後方すべりに関しては, 片岡ら ${ }^{6)}$ は, 後方すべり により dynamic canal stenosis を生じるとし, Pen$\operatorname{ning}^{8)}$ は後方すべりに伴うはさみこみ機構により春髄 症を生じるとした，我々の症例では前方すべり 3 例， 後方すべりは 4 例, 前方すべりは $\mathrm{C} 4 / 5$ が多く, 後方 すべりは C $3 / 4, C 4 / 5$ が多かった。整復位での明らか な脊柱管の狭窄なく，すべりは前方すべりが平均 $3.7 \mathrm{~mm}$ ，後方すべりが $3.0 \mathrm{~mm}$ と，前方すべりが大き い傾向にあった. しかし椎体椎弓間距離に関しては前 方すべりが平均 $12.3 \mathrm{~mm}$ ，後方すべりが $10.5 \mathrm{~mm}$ と後 方すべりが狭窄が強く，後方すべりの方が微小なすべ りで狭窄を生じやすいと考えられた．全 JOA スコア の術前平均は 11.1 で術後平均 14.1 と改善した. 前方 すべりの術前 JOA スコアが平均 10.0 とやや悪いが, 改善率はほぼ同程度であった。術後平均 3.3 ケ月と短 期であるが術後良好であった。 今回整復位での明らか
な狭窄を認めず，微小な不安定性により，髄内高輝度 変化を伴う脊髄症を生じた症例には，カラー固定など 不安定性を防ぐことにより症状改善を認める場合は, 2 椎間までは前方固定術が有効であると考えられた。

多椎間（3 椎間以上）に関してのすべりは今回 経験してないが，片岡ら ${ }^{6)}$ は 3 椎間以上および developmental canal stenosis を伴う場合, 椎弓形 成術を選択している。

\section{ま と め}

(1)不安定性頚椎による頝椎症性脊髄症に対し，前方 固定術（2 椎間まで）を行い，その不安定性および治 療成績について検討した。

(2)全例整復位での脊柱管狭窄はなく, 微小な頝椎不 安定性により脊䯣症を生じた.

(3)後方すべりの方が前方すべりより微小なすべりで dynamic canal stenosis を生じていた

(4)頚椎前方固定術（2 椎間まで）後，短期ではある が，全例改善傾向にあり，経過良好であった.

\section{参 考 文 献}

1）鐙 邦芳：中下位頝椎の安定性：生体力学的検討. 脊 椎脊髄，4(7)：527-534，1991.

2) Epstein, J.A.: The importance of removing osteophytes as part of the surgical treatment of myeloradiculopathy in cervical spondylosis. J. Neurosurg, $30:$ 219-226, 1969

3) Epstein, J. A.: Myelopathy in cervical spondylosis with vertebral subluxation and hyperlordosis. J. Neurosurg, 32 : 421-426, 1970.

4) Etsuo Shoda: Developmental and Dynamic Canal Stenosis as Radiologic Factors Affecting Surgica Results of Anterior Cervical Fusion for Myelopathy. SPINE, $24:$ 1421-1424, 1999.

5）福井康二：不安定頚椎による頝椎症性脊髄症の病態と 治療。臨整外， $24 ： 405-410,1989$.

6)片岡 治：頚椎症性脊䯣症における dynamic canal stenosisについて。臨整外, $10: 1133-1143,1975$.

7）国分正一：頚椎後方すべりの臨床的重要性の検討。臨 整外, 24(4) : 397-403, 1989.

8) Penning, L.: Some aspects of plain radiography of the cervical spine in chronic myelopathy. Neurology, 12 : 513-519, 1962 